Obesity in later infancy is associated with obesity in adult life and should therefore be avoided, for obesity in adult life is dangerous.

It is probably simpler to prevent developing gross obesity than to treat it. In prevention and in treatment a comprehensive approach is needed dealing with the feelings as well as the food intake of the child and his parents.

\title{
REFERENCES
}

American Institute of Nutrition: Symposium on Effects of High Calcium Intakes (I959). Fed. Proc. I8, 1075 .

American Institute of Nutrition: Symposium on Protein Requirement and its Assessment in Man (1959). Fed. Proc. 18, I I25.

Anonymous (196I). Brit. med.F. i, 45.

Apley, J. \& Mac Keith, R. (1962). The Child and His Symptoms. London: Churchill.

Bakwin, H. (I96I). F. Pediat. 59, I 54.

Beaudoin, R., Van Itallie, J. G. \& Mayer, J. (1952-3). F. clin. Nutr. I, 9 I.

Berg, B. N. \& Harmison, C. R. (1957). F. Geront. 12, 370.

Brock, J. F. (editor) (1961). Recent Advances in Human Nutrition. London: Churchill.

Cusworth, D. C., Phansalkar, S. V., Roitman, E., Norton, P. M. \& Snyderman, S. E. (I959). Fed. Proc. r8, 209.

Enos, W. F. Jr., Holmes, R. H. \& Beyer, J. (1955). F. Amer. med. Ass. 158, 92.

Gerschoff, S. N., Legg, M. A. \& Hegsted, D. M. (I958). F. Nutr. 64, 303.

Holt, L. E. Jr. (1960). Postgrad. Med. 27, 783 .

Holt, L. E. Jr. (1961). In Recent Advances in Human Nutrition, Chapter 24. [J. F. Brock, editor.] London: Churchill.

Illingworth, R. S. (1939). Arch. Dis. Childh. 14, I 21.

Illingworth, R. S., Harvey, C. C. \& Gin, S. Y. (1949). Lancet, ii, 598.

Lane, P. W. \& Dickie, M. J. (1958). F. Nutr. 64, 549.

Lát, J., Widdowson, E. M. \& McCance, R. A. (196r). Proc. roy. Soc. B, 153, 347.

McCay, C. M. (1952). In Cowdrey's Problems of Ageing : Biological and Medical Aspects, 3 rd ed., p. I 39. [A. I. Lansing, editor.] Baltimore: Williams and Wilkins.

McCay, C. M., Crowell, M. F. \& Maynard, L. A. (1935). Y. Nutr. 1o, 63.

Macdonald, A. D. (1962). Develop. Med. Child Neurol. 4, 595.

Mackay, H. M. N. (1933). Arch. Dis. Childh. 8, 22 I.

Malmros, H. (1950). Acta med. scand. 138, Suppl. 246, p. I37.

Mayer, J. (1957). Bull. N.Y. Acad. Med. 33, 744.

Parnell, R. W. (1962). Med. News, no. 5, p. 8.

Ross, M. H. (1 959). Fed. Proc. 18, I I90.

Saxton, J. A. Jr. \& Kimball, G. C. (I94I). Arch. Path. (Lab. Med.) 32, 93 I.

Silverberg, M. \& Silverberg, R. (1955). Physiol. Rev. 35, 347.

Simms, H. S. \& Berg, B. N. (1957). F. Geront. 12, 244.

Slonaker, J. R. (193 I). Amer. F. Physiol. 98, 266.

Strom, A. \& Jensen, A. R. (I95I). Lancet, i, 126.

Tannenbaum, A. (1942). Cancer Res. 2, 468.

Wallace, L. R. (1945-6). \%. Physiol. 104, 34 P.

Walter, F. \& Addis, 'T. (1939). F. $\exp$. Med. 69, 467.

Walton, A. \& Hammond, J. (1938). Proc. roy. Soc. B, I25, 3 I I.

Wickes, I. G. (1952). Arch. Dis. Childh. 27, 449.

Widdowson, E. M. (1947). Spec. Rep. Ser. med. Res. Coun., Lond, no. 257.

Widdowson, E. M. (1951). Lancet, i, 13 6 .

Widdowson, E. M. (1955). Amer. F. clin. Nutr. 3, 391.

Wolstenholme, G. E. W. \& O'Connor, M. (editors) (1961). Ciba Foundation Symposium on Somatic Stability in the Newly Born. London: Churchill.

\section{The comparative merits of breast and bottle feeding}

$$
\text { By Mavis Gunther, University College Hospital, London, W.C.I }
$$

Detailed information about the composition and effects of a food, when available and even widely accepted, does not necessarily govern the choosing of that food. 
The choice of method of feeding a baby is made, of course, not by the baby that will take the food but by one or more adults who may be personally very much involved and who are more likely to decide on emotional grounds than on any other. Feeding a baby is a job with its own merits.

\section{Emotional aspects}

The foremost fact is that in almost every instance whoever makes the choice is wishing the baby to thrive. It is believed, on their own evidence, that some fathers are jealous of their babies and for this reason prefer the mother not to feed from the breast but, even so, the father may be taken as wishing, usually passionately, that the baby will thrive. When the mother makes the choice she is going to confirm to herself as she feeds and by the very act of feeding that she is doing the right thing, because to her it is axiomatic that she wants the baby to thrive: therefore she must be doing the right thing. Consequently a woman usually feeds her later children as she had fed her first. A mother's recollection after a few months of how she came to decide on her course of action and how the baby fared is often remarkably inaccurate.

The commonest reason for a mother to choose to feed her baby from a bottle is probably the pleasure of seeing the stuff go in. This pleasure takes thousands of people to the zoo and it warms the hearts of little girls who are allowed to feed visiting babies. It is almost certainly the principal reason why some midwives want a baby to be bottle-fed, and even if the midwife is bored with doing it herself she can still imagine that the mother would like to. Perhaps this is because the bottlegiver has visible proof that he or she is kind, generous and responded to, and also that the food has gone in.

The next reason for preferring the bottle as a method of feeding is that the mother does not feel so committed. Of all the things that happen to a woman, it is the coming of the first child that most truly causes a change of life. For one reason or another many women have little idea of what it will be like. Almost every mother is pleased with her baby and happy to have borne him or her, but with the delivery she hopes for the fulfilment of her unspoken promise that when she is delivered she will be herself again. For some this means going back to being in the community they used to work in; for others the years of endeavour to make themselves into a person with a recognized qualification have left them with the feeling that they must go on with their old job for they can only imagine themselves being the person they have striven for so long to be. To these mothers the child's dependence is basically unwelcome. Many women with insight, that I have known, have felt their mental ability dimmed in pregnancy and subsequently for a short while and have thirsted for the stimulus of company. The prospect of isolation, the inscrutability of a small baby to someone unused to handling one, the prospect of the routine jobs of baby care, together with the well-founded fear that if they do not take up their old job immediately the door will close on them finally, make some mothers feel that they should not devote themselves to the baby. Those who ask a newly delivered woman whether or not she wants to feed from the breast cannot help 
seeing that for many the bottle is a protective mechanism for the mother who fears too binding a demand. There are of course many exceptions to this generalization, but some of the sorrow which midwives sometimes cannot help feeling is not about the denial of breast milk but the suggestion of unwantedness towards the baby. I must add that the apparent early rejection of the baby does not seem to last in most of the mothers but some are believed to be going to grow into cold possessive parents.

Moving across the gamut of those who want to give the bottle and those who do not want to feed from the breast we come to those who are afraid that having food removed is a form of un-eating. This fear underlies some of the tiredness of which some women complain. Next we come to very real reasons for not feeding from the breast: soreness of the nipples, acute mastitis and breast abscess. These troubles are almost completely avoidable, but when the care is insufficient to protect the mother the relative merit of bottle feeding is enhanced. And then there are those who hate breasts and anything to do with them with an intense antipathy. It is likely that there are many psychological factors determining the mother's choice. The two that are often considered to be having an effect are first the way the mother was fed in her infancy and second the mother's attitude as a little girl to the feeding of her siblings.

Still keeping to the choice of method made independently of the comparative merits of the milks, we come to mechanical causes. A baby feeds at first in response to the feel of the shape in his mouth. When the breast is not protractile enough to offer the right shape the baby does not feed vigorously from the mother but is sure to take the commercial bottle teat well, even if it is empty, for the teat has evolved empirically during this century to a shape which is unfailingly effective in evoking feeding behaviour from the normal full-term neonate. It is very hard for the mother to endure the baby's rejection of herself and to watch the baby's responsiveness to the bottle. She soon only wants her baby to have the bottle.

The mother who wants positively to feed from the breast does so primarily because she believes that by doing so she will benefit her baby. The other reasons are its ease, its quickness and a quiet, deep and restful satisfaction which comes to a mother from giving, protecting and feeding. It is believed by some that the emotional relation between the mother and the baby is stronger when the baby has been fed from the breast. This is likely on the evidence of mothers who have fed some of their children from the breast but not others. The point is difficult to prove as mothers who choose one way or another may be different at the outset.

\section{Nutritional aspects}

Human and cow's milk are best compared for their effects on the baby in his freedom from infection, in the health of his body's composition and in his growth.

Infection. In order to consider the relation of a baby's food to processes involved in infection and in immunity to it, it is necessary to go into a series of apparently disconnected subjects. For decades the simple concept has held sway that asepsis ensures freedom from infection. From this it was commonly assumed that surveys comparing the health of babies fed by bottle or from the breast were, 
in effect, measuring the carefulness of bottle givers. 'If one is careful enough there is no risk' people would say. It is not so simple. For instance, some species of malaria parasite are susceptible to sulphonamide, which fact led Hawking (1954), who had been told that the breast-fed baby had a relative immunity to malaria, to investigate the parasite's dependence on the presence of $p$-aminobenzoic acid in the host. The theory is that the parasite requires $p$-aminobenzoate or folic acid in order to multiply and also that $p$-aminobenzoic acid is quickly metabolized or excreted by the host. Frequent partaking of it by the host would then be necessary for the parasites to maintain an infection. In rats and monkeys infection by a suitable species of parasite was prevented by giving a $p$-aminobenzoic acid-free diet from 4 days before attempted infection. Sterile fresh cow's milk was found to be free from $p$-aminobenzoate but bacterial contamination could lead to its formation in the milk. Hawking then investigated the effect of the ingestion of $p$-aminobenzoic acid by the mother monkey on the liability to infection of the baby she was feeding and it appeared that small amounts could be excreted in the milk by primates. It seems that this finding, which is presumed to have its counterpart in man, is of profound importance in explaining how the human species has survived in malarious areas through the course of evolution. It also offers an explanation of the successfulness of lactation in races in tropical regions where natural selection must have ensured that it was so. Since $p$-aminobenzoic acid is widely distributed in food and is probably secreted in human milk, the small frequent limited infection, which would appear to occur judging by Hawking's monkeys, is an effective way of building up the parasite antibodies known to prevent and cure malaria (Cohen, McGregor \& Carrington, I96I).

Preventive medicine must aim at elimination of malaria and rely on antimalarial drugs, but this age-old process of passive immunity derived from the mother, the months of limited infection and the resulting chance to develop active immunity should not be ignored. And the difference between cow's milk with high and low bacterial counts and the likely effects of introducing mixed diets early should be borne in mind.

Much that has been said about malaria can presumably be applied to organisms susceptible to sulphonamides, notably streptococci. Though it is to be expected that the baby receiving human milk or uncontaminated cow's milk should enjoy relative freedom from streptococcal infection it is likely that heavily contaminated milk and the mushes called mixed feeding increase the risk.

It is likely that colostrum, which has the same antibodies and in the same kind of titre as the mother's serum, can protect against ingested pathogens to which the mother had immunity since the pathogens would be coated and lysed if they entered the body proper. The work of Boorman and her colleagues (Boorman, Dodd \& Gunther, 1958), who gave high-titre antirhesus serum with colostrum to neonates, makes it unlikely that the human infant absorbs a significant quantity of antibodies from colostrum to add to those reaching him transplacentally.

It has often been stated that the neonate is a very poor reactor to antigenic stimuli but it is now quite clear that if cow's milk is taken by mouth in the first days of life 
a very vigorous response occurs. In an investigation by Coombs and his co-workers (Gunther, Cheek, Matthews \& Coombs, I962) more than one in ten of the babies studied had formed by to days of age antibodies of as high a titre as is found at any stage of life. Almost all the newborn babies receiving several feeds of cow's milk developed at least a moderate titre. Antibodies were formed to casein, $\alpha$-lactalbumin and $\beta$-lactoglobulin, the three pure components available for testing.

The study of the development of antibodies to cow's milk proteins was undertaken because considerable evidence is accumulating that some at least of the 1400 cot deaths, where a baby is found dead unexpectedly, occurring annually in Britain may be attributable to a modified anaphylactic reaction. In an experimental model, if antibodies are induced in a guinea-pig by injection of cow's milk proteins and then a small amount of the protein is put into the trachea of the animal while lightly anaesthetized, death occurs in a few breaths without a struggle. The post-mortem findings in the lungs of the experimental animal resemble those of the infant dying a cot death. Nearly all the deaths have been found to occur in bottle-fed babies and in most instances the antibody titre has been high. The theory is then that some babies fed early on cow's milk in some form become sensitized and that some inhale regurgitated stomach contents while asleep, and die.

Some points need to be made about the early development of antibodies to cow's milk proteins. First, it is possible that the intense response may monopolize the mechanisms that should be protecting the baby from infection. Second, since a baby forms antibodies to milk proteins taken by mouth, the proteins of other foods ('mixed feeding') must be presumed to be antigenic and the present-day fashion for early introduction of other foods may be building in allergic reactions to, say, beef or gluten which will inconvenience the child later. The work of Truelove (I96I) has shown that an undue proportion of patients with ulcerative colitis have antibodies to cow's milk proteins and were bottle-fed as infants.

An infant's food can affect his health and freedom from infection by mechanisms which are only beginning to be thought of. Doubtless there are others to be discovered.

The early surveys comparing the effects on the baby of feeding with human or cow's milk have been very well summarized by Paget Stanfield in the Norrbotten Study (Mellander, Vahlquist, Mellbin et al. I959). In recent times there have been two large careful surveys. The Douglas (1950) survey, which was based on a properly randomized sample, showed a significantly greater incidence of infection, both of gastro-enteritis and of respiratory infection, among the bottle-fed, and curiously there was also a significantly greater incidence of measles among the bottle-fed. The Norrbotten study was a more intensive study of 402 children by a very large team of workers, twenty of whom contributed to the report. Here again a significantly greater number of infections occurred in the ist year of life among the babies weaned early from the breast compared with those who were entirely breast-fed for $6 \frac{1}{2}$ months or more. And again, although the numbers were small, there was a lower incidence of measles in the breast-fed. This surprising effect is unexplained. Certainly the 
concentration of $\gamma$-globulin as such was not the protective factor since it was significantly higher in babies who were given cow's milk early.

Composition of milk. Apart from the big difference in the composition and concentration of protein, the differences in the composition of human and of cow's milk lie principally in the greater proportion of long-chain unsaturated fatty acids in human milk, the higher dosage and continual totting up with vitamin $\mathrm{C}$ which breast feeding provides and the differences in the content of minerals. The effects of the types of fat have not been determined and the principal interest lies in the minerals. Cow's milk as secreted has about the same content of iron as human milk but tends to have more after processing. Nevertheless in the Norrbotten study the breast-fed babies had a slightly but significantly higher haemoglobin level. The calcium content in cow's milk is roughly four times and the phosphorus content about six times as great as in human milk. In the Norrbotten study the level of serum calcium at $7 \frac{1}{2}$ months of age was significantly higher in the breast-fed babies and those of serum phosphorus and alkaline phosphatase were significantly lower. All babies received vitamin $\mathrm{D}$ daily and there was no radiological evidence of rickets. There was one very interesting finding that there was less caries in the surfaces of teeth laid down while the baby was bottle fed.

Growth. Most babies seem to know when they have had enough but it is not known how far fullness by volume or, say, rising blood sugar determines the endpoint. It is possible to make some babies do with little or to work at getting them to take more. It seems impossible at present to judge how far very ample feeding helps the child to develop physically or mentally. Certainly excessive regard for the qualities of human milk has led many mothers, often at their advisers' bidding, to fail to give cow's milk although the baby is clearly underfed. Inadequacy of a lactation when it occurs seems the most clear-cut disadvantage of feeding a baby from the breast. In the Norrbotten study the cow's milk given to the babies was diluted with an equal volume of water with $5 \%$ sugar and $\mathrm{x} \%$ wheat flour. On this the growth curves for the breast-and bottle-fed were almost indistinguishable. This way contrasts with our local habits of using cow's milk almost undiluted and sometimes with added farinaceous semi-solids. There seems to be little information about the effects of present-day concentrated diets and once again the choice seems to be being made by adults according to their feeling. Exact information is needed.

\section{REFERENCES}

Boorman, K. E., Dodd, B. E. \& Gunther, M. (1958). Arch. Dis. Childh. 33, 24.

Cohen, S., McGregor, I. A. \& Carrington, S. (1961). Nature, Lond, 192, 733.

Douglas, J. W. B. (1950). ₹. Obstet. Gynaec. Brit. Emp. 57, 335 .

Gunther, M., Cheek, E., Matthews, R. H. \& Coombs, R. R. A. (1962). Int. Arch. Allergy, 21, 257.

Hawking, F. (1954). Brit. med. F. i, 425 .

Mellander, O., Vahlquist, B., Mellbin, T. et al. (1959). Acta paediatr., Stockh., 48, Suppl. i i6, p. I 1.

Parish, W. E., Barrett, A. M., Coombs, R. R. A., Gunther, M. \& Camps, F. E. (1960). Lancet, ii, I 106.

Truelove, S. C. (1961). Brit. med. F. i, I 54. 